\title{
THUCYDIDES' GREAT HARBOR BATTLE AS LITERARY TOMB
}

\author{
RACHEL BRUZZONE
}

\begin{abstract}
$\sim$
Abstract: This article argues that Thucydides' Great Harbor scene (Th. 7.69-71) recalls the imagery of the public funerary monuments of this time. Internal focalization encourages the reader to visualize a conflict which remains fixed at a moment of peak strain for a long period in a densely crowded field, the historian directing the reader's attention to one individual conflict after another, an experience much like viewing a frieze. Internal viewers, meanwhile, wail and lament. This ersatz funerary monument complements Nicias' pre-battle harangue, which has long been recognized as unsettlingly funerary, to memorialize men who soon will lie unburied.
\end{abstract}

AfTER PATROClus' DEATH IN THE ILIAD, Homer memorably freezes Achilles' grieving horses in the image of a funerary monument for the fallen hero, characterizing the living creatures as resembling a still and

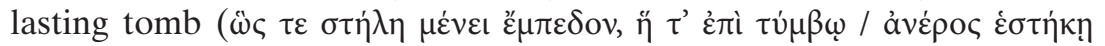

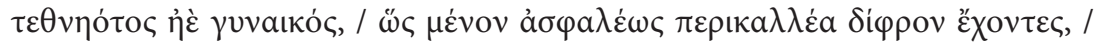

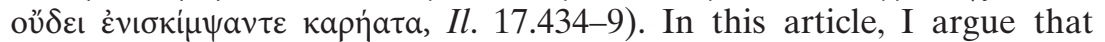
Thucydides' imagery in his narrative of the Great Harbor battle in Sicily performs much the same function, as he freezes the spectacle of the Athenians' last valorous battle into a scene reminiscent of the public monuments for the war dead popular in the historian's time, transforming a real-life action into a kind of ekphrastic image. This interpretation builds on the work of scholars who have observed other markedly funerary elements in the final portion of the Sicilian Expedition, specifically Nicias' oddly funerary pre-battle speech and Thucydides' own epitaph for Nicias. Taken together, these elements suggest that Thucydides fashions the end of his Sicilian Expedition to provide a substitute for the proper, reverent memorial the fallen were denied in real life. The Great Harbor and surrounding narratives can thus be seen adding pathos, replicating the usual rituals in a way that calls attention to their painful absence in real life, as well as implying a memorializing function for the emerging genre of historiography. 
Scholars have long observed that the episodes surrounding the Great Harbor battle scene share an unexpectedly funereal tone. The content of Nicias' pre-battle speech (7.69.2-3) maps onto the most frequent topics in extant funeral orations, but is decidedly atypical for pre-battle speeches in Thucydides. ${ }^{1}$ Indeed, with its appeals to the fatherland, forefathers, freedom, the pleasure of Athenian daily life, wives, children and ancestral virtues and gods (7.69.2), the speech "is more properly a funeral oration in the traditional sense than is Pericles'."' As Rawlings observes, the speech thus serves as a substitute for the proper epitaphios logos preceding burial in Athenian soil that these men, who are abandoned where they fall, do not receive (Rawlings 1981,157). Similarly, Steinbock has recently argued that Thucydides seems to supply an ersatz tomb for Nicias, a man deprived of a physical memorial, by endowing him with an "epitaph" (7.86.5; Steinbock 2017, esp. 122-35). A representation of the famous Great Harbor scene as specifically funerary would thus be in keeping with the established themes of this portion of the History, in which the historian appears to be assembling on a literary level the central features of a public funeral, both rhetorical and material, in order to honor the fallen in a way that real-life circumstances prevented.

Such a reading would explain some unusual features of the episode. This is far from a sequential account of key strategies and crucial turning-points, as most Thucydidean battle narratives are, a fact that has drawn comment and even complaint from historians. ${ }^{3}$ Instead, the scene is famous for its visual qualities, beginning with Plutarch's praise of its enargeia (Mor. 347a), which he says renders the hearer a sort of viewer. ${ }^{4}$

${ }^{1}$ Carmona Centeno 2012,109, observes that this speech is unusual, in that it does not help the reader understand the coming conflict. Rawlings 1981, 154-61; Rood 1998, 193-4; Grethlein 2008, 234-5; and Hornblower 2008, 692, discuss the parallels between Pericles' and Nicias' speeches. On other similarities between the Funeral Oration and the end of the Sicilian Expedition, and especially Nicias' speeches, see Bassi 2007, 192-6.

${ }^{2}$ Rawlings 1981, 155-7. He further observes that both speeches refer to great contests $(2.42 .1,7.69 .2)$; that Nicias' exhortation not to fall short of paternal virtues resembles 2.36.1 and 41.3; that Nicias' appeal to the freedom of the fatherland further reflects 2.36.1 and 37.2; and that the appeals to wives and children also belong to the genre of funeral oratory. Ziolkowski 1985, 59, observes that a funeral speech usually appeals to "fatherland, ancestry, nature, training, accomplishments," as Nicias' speech does.

${ }^{3}$ CAH 5.308: "At this point Thucydides fails even to suggest the factors that determined the outcome. Instead, he dwells on certain typical incidents in the confused fighting that follows, and then turns our attention to the spectators on the shore." See Bakker 1997, 41, Hornblower 2008, 693 and Lendon 2017, 160, for similar observations.

${ }^{4}$ For modern treatments of the vivid power of Thucydides' writing, especially with regard to the Great Harbor passage, see Walker 1993 and Carmona Centeno 2012, 110. 
This emphasis on the visual has led to the Great Harbor scene being taken to recall tragedy. ${ }^{5}$ The emphatically static nature of the battle, however, seems to argue against the stage as its inspiration; as Aristotle notes, one central feature of tragedy is progressive action (Po. 1450a), while this scene seems fixed for an eerily long period of time, as is discussed below.

In what follows, I begin with the first occasion this army served as a spectacle, its departure from the Piraeus. This scene has long been observed to be hollow and deceptive, the Athenian spectators finding their show of force impressive despite its superficiality and the participants behaving as if they are engaged in playful competition among friends rather than risking their lives and empire. I argue that this initial "misinterpretation" of spectacle will be answered, and corrected, by the second such scene featuring the same men, in which funerary imagery makes clear the deadly, rather than lighthearted, reality of the enterprise. Before arguing for this funerary character of the Great Harbor scene, I briefly establish that allusion between literary and visual arts is entirely in keeping with the literary practices of Thucydides' day. I next discuss the typical features of visual representations of battle and observe their similarities with the Great Harbor episode, noting as well the specifically funerary features of the scene constructed by Thucydides. I conclude by discussing the implications of this allusion for Thucydides' program as a whole, in that it implies a memorial function for historiography and gives his work much the same role as that of a physical tomb, like Homer's Iliad is sometimes imagined to have. ${ }^{6}$

\section{THE FIRST IMAGE: THE ATHENIANS DEPART THE PIRAEUS}

The men who take part in the Sicilian Expedition are represented as a spectacle not once but twice, first as they leave the Piraeus on their way to Sicily (6.30-1, see, e.g., Jordan 2000; Kallet 2001, 21-82; Steiner 2001, 209), when Thucydides notes that their families and friends had come to bid them farewell (6.30.2). There are significant reminiscences between the Piraeus departure and the Great Harbor battle, the Sicilian Expedition's optimistic beginning and the moment spelling its catastrophic end. Like the later episode, the departure is cast in markedly visual terms, being

${ }^{5}$ De Romilly 1956,160-4. Hornblower 2004, 342-6, has argued that the Great Harbor scene reflects both athletic and theatrical scenes.

${ }^{6}$ E.g., Clay 2011,119: "Indeed, the poem as a whole can rightly be considered a sema actualized in the poet's memory and activated in each performance." 
"renowned for the splendor of its opsis" (6.31.6) and Thucydides himself deeming it $\varepsilon \dot{\pi} \pi \rho \varepsilon \pi \varepsilon \sigma \tau \dot{\alpha} \tau \eta$ (6.31.1). A lust for various types of seeing drives the Sicilian Expedition ( $\pi$ ó $\theta \omega$ ö $\psi \varepsilon \omega \varsigma$ кaì $\theta \varepsilon \omega p i a \varsigma, ~ 6.24 .3)$, and many have noted that the entire opening of the Expedition is presented as a visual experience (See especially Kallet 2001,21-82). The ships are fitted out beautifully, and the men have likewise invested in equipment (6.31.3). Like the Great Harbor battle, this departure is largely focalized through the eyes of the spectators, among whom the Athenians wonder whether

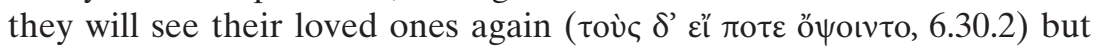
take comfort in the vision before them ( $\dot{\varepsilon} \omega \rho \omega v ;$ ö $\psi \varepsilon \varepsilon, 6.31 .1)$. The foreigners, on the other hand, are simply impressed by the worthy and incred-

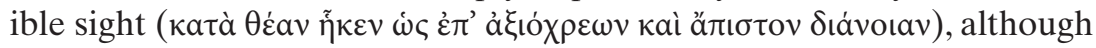
Thucydides notes that other Greeks viewed it as a hollow display rather than a real demonstration of power (6.31.4).

As has been observed, the departure scene is the only communal gathering described by Thucydides except for the public funeral of Book 2 (Steiner 2005, 418). In itself it has reminiscences of a funeral, as most of the spectators are indeed laying eyes on their loved ones for the final time, just as they consider might be the case (6.30.2). Thucydides' description of the assembly enhances this hint at the deaths to come, especially his observation that, in the midst of the happy gathering, a sudden appearance is made by grief (ỏ $о \varphi \varphi \rho \mu \tilde{\omega} v, 6.30 .2){ }^{7}$ a term that appears elsewhere most prominently in the Funeral Oration and the Great Harbor scene, as is discussed below. This feeling is fleeting for Thucydides' characters but ominous for the reader, pointing forward to the end of the Sicilian Expedition and especially the collective mourning that will take place the second time the Athenians are presented as a visual marvel, in the Great Harbor.

Other features as well encourage comparison between the two episodes, especially their shared language of competition. Like the Great Harbor episode, the departure involves strife among allies trying to prove

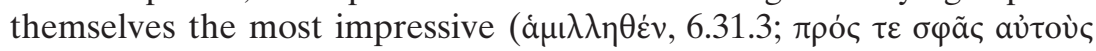

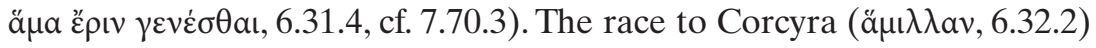
is described with the same term as the far more serious struggle in Sicily ( $\dot{\alpha} \mu i \lambda \lambda \eta \varsigma, 7.71 .3$ ), among other reminiscences, and both spectacles have

${ }^{7}$ Hornblower 2008, 383, on 6.30 .2 observes that the "hope and lamentation" with which the fleet departs looks forward to similar emotions at 7.71.3-4 and 75.2. Mackie 1996, 108-9, takes the departure scene as Homeric. 
sometimes been thought to recall athletics as a result of the presence of spectators and the competitive nature of the events. ${ }^{8}$

Many scholars have seconded Thucydides' internal observers in their opinion that the beautiful departure scene represents a hollow illusion (6.31.4; see Ober 1998, 114-15, esp. 114 n. 114; Kallet 2001, 21-82). Kallet has made this argument most thoroughly, arguing that the departure inverts Pericles' boast that Athens uses its wealth for power rather than show (2.40.1), and that the display thus produced is deeply deceptive. ${ }^{9}$ The specific nature of the misapprehension seems to be confusion between one type of competition and another, as the Athenians undertake a lethal war as if it were an athletic contest put on for the pleasure of spectators. If the final spectacle in the Great Harbor is taken to be funerary, the juxtaposition of the scenes at the beginning and end of the Sicilian Expedition work together to correct this misunderstanding with the painful truth. The Athenians begin what turns out to be a deadly serious conflict as if it were a game, only to realize later on the mass casualties that it will inflict. The illusory athletic imagery at the opening of the Expedition, followed by the apparent funerary imagery at its close, reflects this self-deception and belated comprehension. Kallet observes that in Thucydides "opsis is often truly understood only at the moment of destruction" (Kallet 2001,22; see also 168-9 on this type of "recognition scene"). If the Great Harbor image is taken to be funerary, it performs this function, responding to the mirage-like first image and correcting the Athenians on the nature of the conflict they have unleashed in Sicily just as the possibility of salvation slips definitively out of their hands.

\section{GREEK LITERATURE AND THE VISUAL ARTS}

The highly visual nature of both of these scenes may be understood to take on additional significance because Thucydides composed his work within a literary culture that frequently engages with the world of material arts. Reading and visualization are often implicitly treated

${ }^{8}$ E.g., Jordan 2000,76-9, discusses the significant reminiscences between the departure and the defeat, arguing that they engage with Alcibiades' status as an Olympic victor, while Hornblower 2004, 342-51, takes the two corresponding sections to be using athletic imagery.

${ }^{9}$ Kallet 2001, 21. Other elements of the Sicilian Expedition also depend on illusion, such as the Egestans' offer of financial assistance and Alcibiades' claims of wealth (Kallet $2001,27-8,38)$. 
as analogous in ancient thought, ${ }^{10}$ and explicit discussions confirm this view, sometimes presenting an author's accomplishment as resembling that of a material artist. Simonides famously described painting as silent poetry, poetry painting that speaks (Plu. Mor. 346f); Aristotle presents the goals of writing and sculpture as comparable (Po. 1450a); Dionysius of Halicarnassus praises Homer's ability to make the reader "see" (Ant. Rom. 11.1.3; Walker 1993, 364); and Lucian considers the historian's goal to be to "show" the reader events in order to become a "Phidias of history" (Hist. conscr. 51; Walker 1993, 353). The earliest Greek literature encouraged this intertwining of the visual and literary by displaying a marked interested in approximating visual experiences, as Clay argues, for example, in her Homer's Trojan Theater,${ }^{11}$ and later drama continues to show a fascination with the visual arts (see esp. Stieber 2011). Ekphrastic scenes, a particularly striking manifestation of enargeia, could engage with one another on a literary level, developing practices such as the use of the imperfect discussed below, as well as representing a sophisticated interaction with the visual. Another point of contact between the literary and the visual arts among Thucydides' contemporary authors was allusion to specific recognizable types of imagery, e.g., by "replicating" popular scenes from vase painting in textual form. ${ }^{12}$

The distinction between a human body and the statuary representing it could be similarly elided,$^{13}$ as I argue Thucydides does in presenting the men of the Sicilian Expedition as taking on the appearance of their own tomb. Both texts (e.g., Pi. P. 7.1-3; Hdt. 1.1) $)^{14}$ and living people (e.g., $A R V^{2} 336,14$; see Steiner 1998, 130-1) can be treated as similar to stone, especially in contexts focused on the preservation of memory. This blur-

${ }^{10}$ Webb 2009, 19: "the many reports of the visual impact of reading texts from classical antiquity make it clear that intense imaginative involvement with the scenes described was a common type of response." Chaniotis 2013, 59, discusses the idea that "spectators, readers and listeners are transformed into eye-witnesses through the power of the vivid description," an ancient scholarly reaction to literature that goes back at least to Arist. Po. 1455 24. On using the imagination to construct enargeia in the Iliad, see Clay 2011, esp.1-37. On visualization of battle in early lyric poetry, see Swift 2015. See also Bassi 2016, 74-5.

${ }^{11}$ See Clay 2011, passim for the visual nature of the Iliad. At 36, Clay discusses cinematic aspects of the text.

${ }^{12}$ E.g., Jouan 1966, 438; Barlow 1971, 20; Sousa e Silva 1985-6, 17-19; Rehm 1994, 86; Zeitlin 1994, 176-7; Zeitlin 1995, 185; Golder 1996, 19 n. 30.

${ }^{13} \mathrm{On}$ the marked interchangeability of statuary and human beings in 5th-century literature, see Stieber 2011, 117.

${ }^{14}$ See Steiner 1998,139 on the Pindar. For a particularly useful discussion of the "new poetics of the material world," especially in Simonides and Pindar, see Porter 2010, 462. 
ring of boundaries is particularly marked in the context of tombs; for a few examples, Euripides' Alcestis seems to erase the distinction between the woman and her memorial deliberately (Stieber 1998), while else-

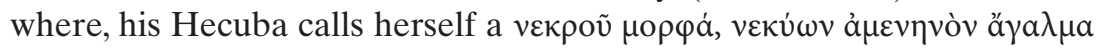
(Tr. 192-3; Stieber 2011, 123). Extant grave-markers treat their role as similarly ambiguous, for example when "speaking" to the passer-by in the voice of the dead (e.g., the Pollis stele of a hoplite soldier) or suggesting amalgamation of the stele and the interred individual (e.g., Phrasiklea; see also Lattimore 1942, 243-5 on $I G$ 2, 444).

\section{TOMB AND BATTLE IMAGERY IN THE PELOPONNESIAN WAR ERA}

Tombs underwent a creative flowering in the Peloponnesian War era as striking grave markers reemerged after a period of restraint. ${ }^{15}$ The friezes depicting battle scenes that began to appear on public monuments, bursting with action and crowded with figures, stand in contrast to the usually subdued imagery on Greek tombs ${ }^{16}$ and they would presumably have seemed meaningful and innovative to many of Thucydides' generation. Their attractiveness and influence are evident when, slightly later, individual tombs begin to challenge or borrow from them, ${ }^{17}$ and the appealing nature of this new element of the Athenian topography may have drawn the attention of the historian, as well.

The imagery that appeared on public tombs would have been largely consistent, opening the possibility for literary allusion to it such

\footnotetext{
${ }^{15}$ Stewart 1990, 62-3, discusses the increasing demand for private memorials at the end of the fifth and beginning of the fourth century. On Greek burial practices for the war dead, see, e.g., Pritchett 1975-91, 4.106-24 and Morris 1992, 128-56. Shapiro 1991 traces the evolution of Athenian funeral iconography from the Archaic into the Classical period. Meyer 1993 explores Athenian civic identity in this context. On the development of funerary reliefs in this period generally, see Walter-Karydi 2015, 181-5.

${ }^{16}$ Richter 1954, 49; Grossman 2001, 98. Early gravestones that do not show men in battle sometimes have them in active, tense postures. For one example, Copenhagen, $\mathrm{Ny}$ Carlsberg Glyptotek 2787 (c. 500 B.C.E.) depicts a pair of hoplites, one crouching.

${ }^{17}$ E.g., Clairmont 1983, 68. Their characteristics were recognizable enough to be meaningfully borrowed or repurposed within visual arts. Osborne 1998, 14-16, discusses the fourth-century private Dexileos tomb's borrowing of the established imagery of public monuments to elevate an individual. Hurwit 2007, 44 argues that the Chalandri relief (c. 420 B.C.E., Berlin, Staatliche Museen, Antikensammlung SK 742) adopts but ultimately challenges the ideology of public monuments with their celebration of the polis rather than the individual.
} 
as I argue Thucydides produces. Public tombs were never plentiful and most are lost, but enough evidence remains from them and from related genres of visual art to allow us to surmise what their typical features were. Portions of several presumably public friezes are extant: the Oxford Relief at the Ashmolean Museum from the second half of the fifth century (Michaelis no. 85); the Palaiologou Relief from the 420s (Athens, Third Ephoreia M 4551; Parlama and Stampolidis 2000, 396-9); and CAT 2.131 (Athens National Archaeological Museum 2744) from 394/3 (Arrington 2015, 103). A stone from around 390 and featuring hoplites in a variety of poses may also be part of a public memorial (New York Metropolitan Museum of Art 29.47). The Albani Relief of the late fifth or early fourth century (CAT 2.131, Villa Albani 985) is another possible example, but might instead be a private marker modeled on public ones (Arrington 2015,229-30). The Chalandri Relief (c. 420, CAT 2.130, Berlin, Staatliche Museen, Antikensammlung SK 742) similarly appears to be private (Arrington 2015, 230-2). Another stele from the late fifth century depicting two hoplites is likely a private monument that adopts elements familiar from the demosion sema (CAT 2.192, Metropolitan Museum of Art 40.11.23, Goette 2009, 196), as does the Dexileos Relief (CAT 2.209, Kerameikos P 1130, from 394, Osborne 1998, 14-16). Another tomb or cenotaph has three sides, using a variation on the Dexileos motif (CAT 2.213, Athens NM 3708). Finally, a private tomb for a soldier named Stratocles from the late fifth or early fourth century depicts vivid action, one hoplite at the moment of slashing another (CAT 2.217, Boston Museum of Fine Arts 1971.129). ${ }^{18}$ Taken together and supplemented by related visual representations of conflict, such as architectural sculpture, these monuments establish a standard visual vocabulary of violence in battle.

One characteristic of physical representations of battle and fight scenes, funerary or otherwise, is crowding, a feature that becomes especially marked during the Peloponnesian War period. Boardman observes that "no earlier pediments were so cluttered" as those of the Parthenon (Boardman 1985, 99; see also Connelly 2014, 95-6), the crowning sculptural work of Thucydides' lifetime. The temple to Nike, constructed during the Peloponnesian War, featured battles on its pediments rather than leaving them blank, as was usual for Classical Ionic buildings (see, e.g., Schultz 2009, 128). The Bassae frieze, completed around 400 B.C.E., is so crowded that it has been judged aesthetically problematic (e.g., Ridgway 1966, 201-2; Stewart 1990, 170). The surviving funerary monuments share

\footnotetext{
${ }^{18}$ On this final motif in other types of memorials as well, see Grossman 2013, 49.
} 
this characteristic. The Palaiologou relief (420-400 B.C.E.), for example, is filled with fallen and fighting men and rearing horses (Athens, Third Ephoreia M 4551); another shows a nude solder attacked simultaneously by a hoplite on one side and a horseman on the other (Athens National Archaeological Museum 2744), while what is likely a votive relief shows the living and the dead tangled among one other (Metropolitan Museum of Art 29.47, Arrington 2015, 196). The strikingly dense composition of a memorial for a fallen soldier named Stratocles, probably from the early fourth century, has likewise been noted. ${ }^{19}$ Similarly, a fifth-century votive relief from Eleusis belonging to a certain Pythodorus depicts several levels of fighting soldiers, making it difficult to identify Pythodorus himself. ${ }^{20} \mathrm{~A}$ tomb featuring a favorite posture that perhaps originated in a painting in the Stoa Poikile, the Dexileos Motif, has a mounted horseman improbably stabbing a foe directly under his horse, the three figures piled on top of one another. ${ }^{21}$ The chaotic depiction of warfare as massed single-combat on these works is fundamentally different from that which Thucydides usually prefers, with his tendency to analyze the action of organized and largely coherent groups such as battle lines or wings of fleets. ${ }^{22}$

A visual depiction of battle stops narrative time, permanently suspending the action, and the significant moment that many visual artists selected to freeze in this way was the climactic instant of maximum tension, the outcome of the conflict hanging perfectly in the balance. Indeed, Plutarch points to the Great Harbor battle's tension and equal balance in his argument that it resembles a work of graphic art (Mor. 347b-c). While not every wall painting depicts this critical instant, ${ }^{23}$ their predilection for such scenes has long been observed. Among examples of this taste for balance, Pausanias characterizes several of the paintings he saw

${ }^{19}$ Clairmont 1972, 49 on the early fourth-century Boston 1971.129, CAT 2.217.

${ }^{20}$ Osborne 2010, 256, on a relief that probably dates to the late fifth century (Eleusis Museum 51). P 1130 .

${ }^{21}$ On the implausibility of the pose, see Hurwit 2007, 41, on CAT 2.209, Kerameikos

${ }^{22}$ The classic example of a Thucydidean battle narrative is usually taken to be Mantinea (4.96), in which the historian clearly describes the arrangement of the men on the battlefield (4.94); their motion across it or lack thereof (4.96.1); and the results of the battle for each army, categorized according to left, right and center (4.96.3-4). For a similar example in a naval conflict, the historian describes the arrangement of Phormio's fleet by wing (2.90.1-2), their collision with the enemy (2.90.4-5), and the results of the conflict for each division (2.90.5-6).

${ }^{23}$ E.g., Paus. 1.15 .3 on the Marathon painting; see Harrison 1972 and StansburyO'Donnell 1999, 143-5, on this unusual painting. 


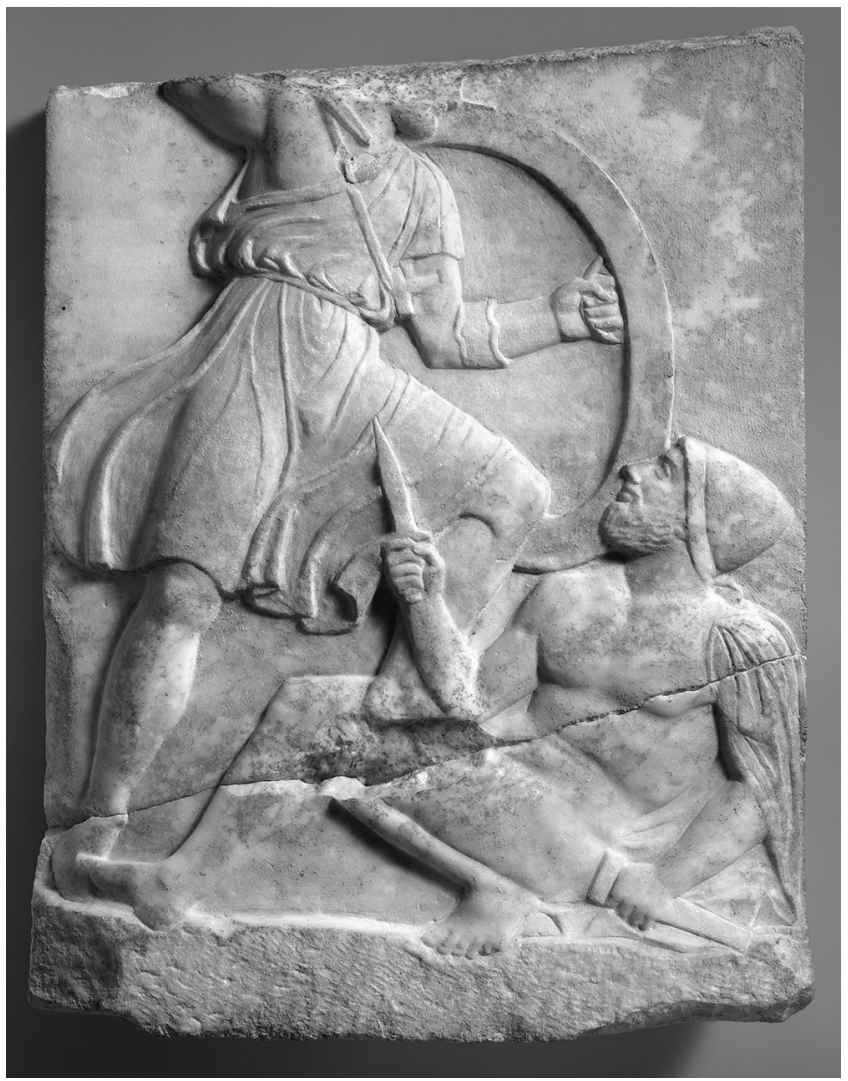

Figure 1. Bassae Relief. (C) Trustees of the British Museum.

as showing equal action on both sides that is successful in some places, while meeting defeat in others, and feels moved to point out a case when

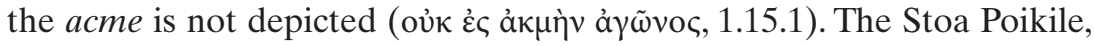
painted in the middle of the fifth century, depicts the opening of the Battle

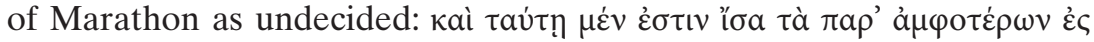
tò épyov (1.15.3). A painting in the Theseion similarly depicts an Ama-

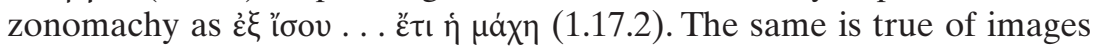
on the Parthenon, ${ }^{24}$ and indeed the Acropolis as a whole (Hurwit 1999,

${ }^{24}$ Osborne 1994, 68: "The stress here is on the conflict, not on showing one or the other side gaining the upper hand." 
231). A similar preoccupation is apparent in many vase paintings of the High Classical period, which also favor suspenseful, undecided conflict, with some on each side of a battle winning and others losing. ${ }^{25}$ While undecided struggle is a favorite motif in many visual arts, it was especially central to the ideology of tombs, as Arrington has shown (Arrington 2011 and 2015). Athenian monuments appear to call attention to the steadfast struggle and resolve of the dead, the visual manifestation of the idea of an agon, as is seen on such monuments as the Oxford relief or the tomb for the dead in the Corinthian War (Arrington 2011, 179; 2015, 104-8).

Another common characteristic of representations of battle in this period is a propensity for depictions of violence that represent elite ideology more than historical battlefield reality, an idealized version of hoplite warfare overlaid with reminiscences of Homeric single combat. ${ }^{26}$ Literary

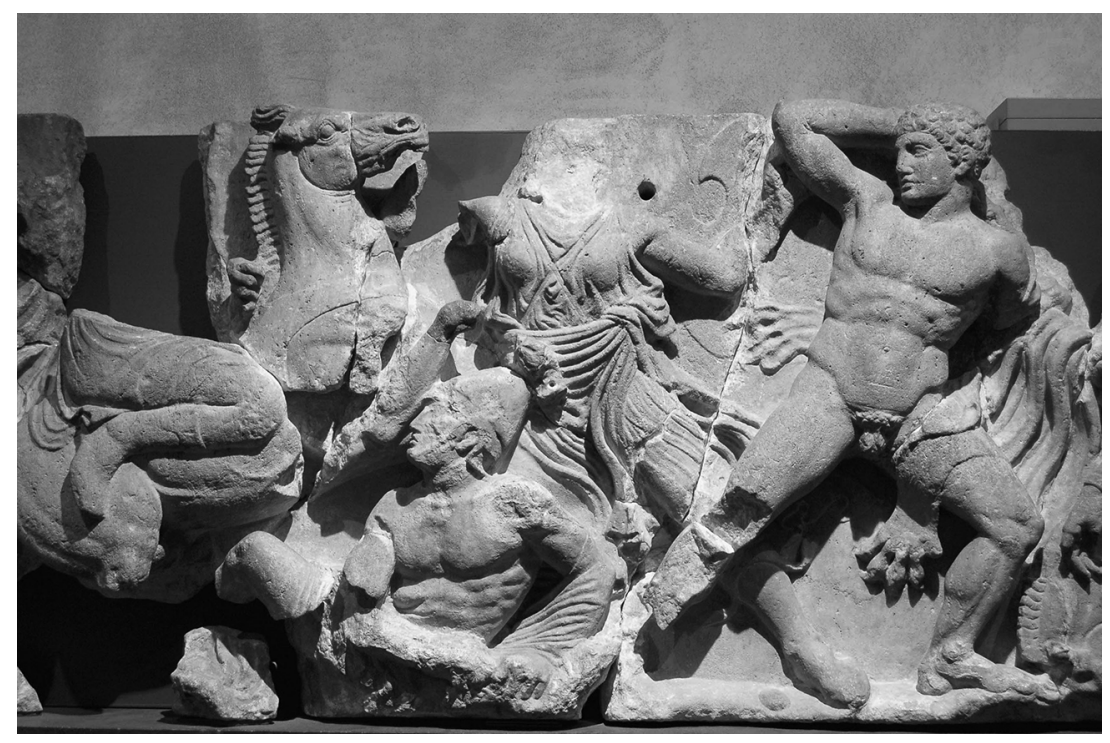

Figure 2. Fletcher Fund, 1940 (40.11.23) Image () 2018, The Metropolitan Museum of Art/Art Resource/Scala, Florence.

${ }^{25}$ Muth 2008,546, argues that the interest of early scenes of hoplite battle is primarily focused on "Kräfteverhältnis" rather than a clear distinction between victor and defeated.

${ }^{26}$ E.g., Snodgrass 1967,101; Miller 2010,331; Arrington 2011,190. Arrington 2015, 112 comments: "These did not offer realistic pictures of warfare. ... Instead, they illustrated an attitude and resolution (gnome) best conceived through one-on-one encounters but which 
accounts of battle usually display a similar bias, favoring depictions of conflict on land and often casting it as single combat. ${ }^{27}$ Both literary and visual depictions of combat tend to avoid "low-class" activities such as seamanship. ${ }^{28}$ One extant private gravestone, from around 400 B.C.E., features the dead man on a trireme. As Miller observes, however, it is significant that he is armed as an epibates; he is presented as a seafaring hoplite ${ }^{29}$ just as the men aboard the ships in the Great Harbor will be.

\section{THUCYDIDES' GREAT HARBOR SCENE AS LITERARY TOMB}

Thucydides thus composed his work in a context in which literature and graphic arts interacted significantly. The process of reading was treated as a more pictorial experience than it might be today, and the historian appears to be particularly interested in issues related to vision in his account of the Sicilian Expedition, presenting the reader with impressive spectacles at its opening and toward its close. Additionally, visual representation of battle scenes, whether on funerary monuments or elsewhere, tended to share a set of typical characteristics that would have been readily recognizable to Thucydides' contemporaries, making literary allusion to them possible. Furthermore, recent innovations in decorated funerary monuments would have kept them fresh in the mind's eye of his contemporary audience. This background allows for a reading of the final spectacle of the Sicilian Expedition, which shares notable features with plastic representations of battle, in a funerary light.

Much as tragedians tend to call attention to sight in passages that have been argued to engage with the visual arts, ${ }^{30}$ ekphrastic scenes do the same (e.g., Zeitlin 1995, 176-7; Elsner 2007, 20), and Homer makes

had to be shared by all Athenians." The Chigi vase with its phalanxes (c. 650-640 B.C.E.) is a notable exception.

${ }^{27}$ E.g., Pl. Mx. 237a; Aesch. Th. 423-37; Soph. Ant. 51-2. Lendon 2005 discusses the influence of Homer on ancient ideas about war. On the contradictory place of the navy in Athenian society, see Hunt 1998, 122-6. Loraux (1981, 132, 267-9) discusses the issue with regard to funeral orations.

${ }^{28}$ Whether oarsmen were included in public cemeteries is unknown. See, e.g., Strauss 2000, 265; Miller 2010, 328.

${ }^{29}$ Miller 2010,330-1, on Athens National Museum 752. See also Stupperich 1994, 97; Goette 2009, 199-202; Steiner 2005, 415-17.

${ }^{30}$ E.g., the emphasis on sight when Iphigenia is sacrificed ( $\left.A g .240\right)$, which Zeitlin 1995, 188-91, argues may derive from a painting of Timanthus. 
spectators a prominent part of the Shield of Achilles and other especially "visual" episodes, ${ }^{31}$ so too Thucydides' choice to present the Great Harbor battle largely through the eyes of internal observers encourages the reader as well to visualize the events described. Beginning and end of the collision are punctuated by references to the spectators (7.69.3) and their view of the battle (7.71.2-3). These and other insistent references to the appearance of the battle and surrounding episodes have been most thoroughly explored by Kallet, ${ }^{32}$ focusing especially on emotion and the interpretation of vision. By employing these spectators as focalizers, Thucydides does not allow his readers to forget that they, too, should keep in mind the appearance of the battle.

The picture that is so emphatically painted in the mind's eye of the reader "looks like" a battle scene from the visual arts of Thucydides' era, sharing the key features of crowding, balanced tension and mass single combat. As other authors do in passages that have been read as exceptionally "visual," ${ }^{33}$ the historian takes particular care to create a sense of the Great Harbor scene's spatial arrangement. Just as "public friezes contained multiple figures filling up the width of the stone" (Arrington 2015,228), Thucydides creates an image of a space completely filled with fighting. He reports that the Syracusans approach and attack from all

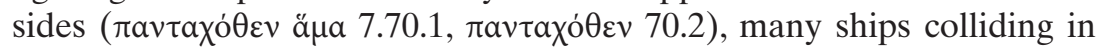

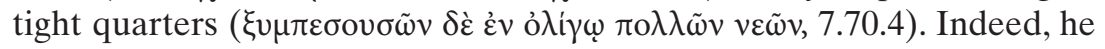
claims that this was the greatest number of ships to fight in the narrowest space ever ( $\pi \lambda \varepsilon \tilde{\varepsilon} \sigma \tau \alpha \iota . . . \dot{\varepsilon} v \dot{\varepsilon} \lambda \alpha \chi \dot{i} \sigma \tau \omega \dot{\varepsilon} v a v \mu \alpha \dot{\chi} \eta \eta \sigma \alpha v, 7.70 .4)$, apparently without qualification, although the Great Harbor of Syracuse is not particularly small and the vast majority of the battle described takes place not in a corner of but across it (7.70.2), while other naval encounters, such as the first sea-fight at Corcyra (1.46-7), involve more ships. The historian nevertheless describes the harbor as so full that there is hardly room for movement, ships colliding with one another whether in pursuit or flight and producing dense collisions (7.70.4), a situation that recalls compact scenes of battle in which violence comes from all sides such

${ }^{31}$ Clay 2011, 9, for example, observes that spectators are a frequent presence on the Shield of Achilles (e.g., 18.495-6, 502, 514, 123-4).

${ }^{32}$ Kallet 2001, 163-9. For example, Nicias urges his men to consider the impressive

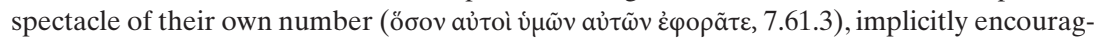
ing the reader to do imagine the sight. He exhorts his troops to keep their ancestral honor

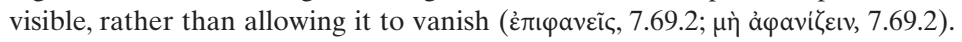

${ }^{33} \mathrm{On}$ the emphasis on spatial relations in such episodes in Euripides, see, e.g., Zeitlin $1995,185-7$. 
as, for example, the Bassae frieze. These collisions occur, he reports, "in many places, because of the narrowness" (7.70.6). Ships simultaneously collide and are collided with, the repeated use of the word enhancing the

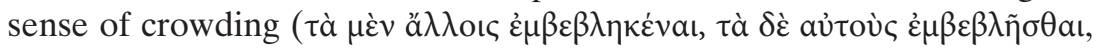

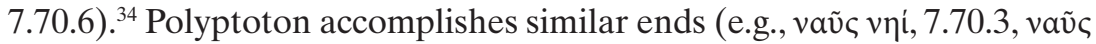

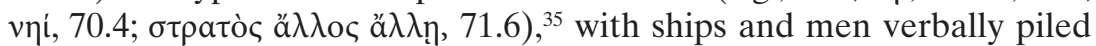

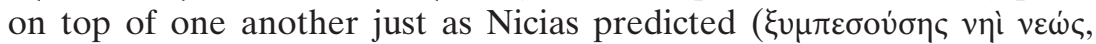
7.63.1), producing more of a resemblance to the dense verbal drumbeat of dithyramb than to Thucydides' usually relatively orderly battle lines. ${ }^{36}$ This piling up recalls the visual elements of friezes; whether a reader sees the words' proximity or a hearer notes the verbal repetition, the polyptoton contributes to the already markedly dense feeling of the passage. Thucydides states that the scene is indeed so jumbled that two or more ships occasionally become tangled around one, while captains look to defense in one place and offence in another, attending to everything from

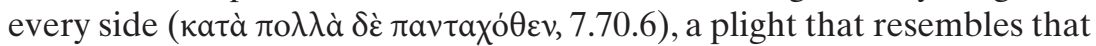
of men in battle imagery such as the Siphnian Treasury at Delphi, with attacks coming from all corners.

The tense and balanced nature of the image is repeatedly emphasized by Thucydides. He reports that men on the shore view undecided

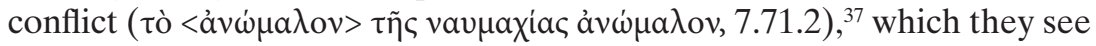
clearly due to its proximity (7.71.3), an invitation to the reader to envision the same scene. The soldiers do not all look in the same direction (7.71.3), and, beholding small encounters rather than coherent battle lines, some

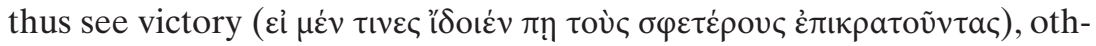
ers defeat (oi $\delta$ ' $\dot{\varepsilon} \pi \dot{\imath}$ тò $\dot{\eta} \sigma \sigma \omega \dot{\mu} \mu \varepsilon v o v \beta \lambda \dot{\varepsilon} \psi \alpha v \tau \varepsilon \varsigma$ ), while still others look upon

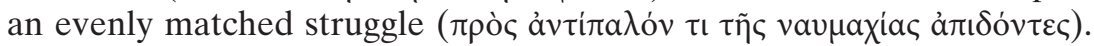
This balanced triad of visions creates a sense of perfectly symmetrical fates in the battle, and Thucydides reinforces this sense when he reserves the most narrative detail for the plight of those viewing the equal battle, describing the men's bodies rocking with anticipation as "they were always on the point of either escape or destruction," just as a viewer of tombs

\footnotetext{
${ }^{34}$ As Hornblower 2008, 695, notes, there is unusual verbal repetition in the Great Harbor scene, enhancing the sense of closeness.

${ }^{35}$ Wills 1996, 198, argues that Vergil's use of "battle polyptoton" "gives us a picture of dense and balanced fighting, combining both the parallel image of the battle lines and the intense proximity of the fighters."

${ }^{36}$ See, e.g., LeVen 2013, 46-50, on Timotheus' Persians with its striking, crowded imagery.

${ }^{37}$ This is a problematic passage, which Smith's Loeb translation (143) interprets differently.
} 
such as the Palaiologou relief would see Athenians encountering both defeat and victory. ${ }^{38}$ As some Athenian spectators call out "we win" while others lament "we lose" (7.71.4), they vividly express an interpretative difficulty familiar for viewers of the balanced battles in the visual arts: "Dem Betrachter wird einerseits die Überlegenheit mancher griechischer Hopliten vorgeführt, anderseits aber auch das kraftvolle und teils sogar überlegene Auftreten mancher Amazonen gezeigt und damit die griechische Überlegenheit gleichzeitig wieder in Frage gestellt" (Muth 2008, 381-2).

Funerary imagery seems to represent idealized struggle rather than defeat or victory and the term agon appears in epigrams to describe the labor of the dead. ${ }^{39}$ Thucydides calls attention to these same concepts by allowing his characters to muse on the approaching conflict and its prizes in language that joins the concepts of struggle, honor and beauty

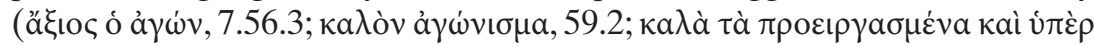

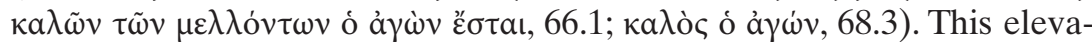
tion of the agon into the abstract, an entity that can in itself be good and beautiful, recalls the similar privileging the idea of the agon in funerary contexts. ${ }^{40}$ Repeated discussion of a kalos agon just prior to a battle with high mortality also evokes the concept of the beautiful death chosen by men who fall in battle (e.g., Pl. Lg. 944c; Lys. 2.79; Dem. 60.26). This same ideology is reinforced by Nicias, who in his pseudo-funerary speech exhorts his men that they must "become agathoi andres" (ảva $\gamma$ кaĩóv $\tau \varepsilon$ ôv

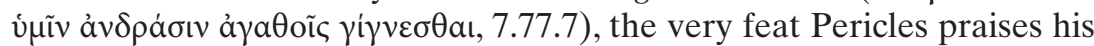

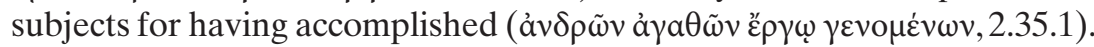
The pre-conflict contemplation of a glorious agon and hints at honorable military death are particularly painful because the fate of many of these men, whose abandoned bodies will decompose in the open, terribly inverts the ideology of the public funeral usually awarded men who fall in battle (Vernant 1982,69). During the conflict as well, Thucydides keeps

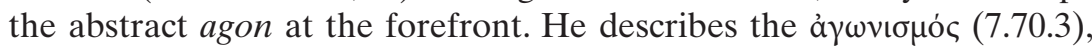
a particularly notable word, given its rarity. ${ }^{41} \mathrm{He}$ further reports that the agon between the two sides is augmented by competition within each force (7.70.3), and even those watching from the shore experience $\pi$ ròvv

${ }^{38}$ On the mix of victory and defeat on this and other tombs, see Arrington 2011, 198.

${ }^{39}$ E.g., $I G \mathrm{I}^{3} 1163 \mathrm{~d}-\mathrm{f}$ (Arrington 2015, 105-7).

${ }^{40}$ E.g., Arrington 2011, 183: "they commemorated collective courage and sacrifice ... to create a visual rhetoric of collective resilience and continuous struggle (agon)."

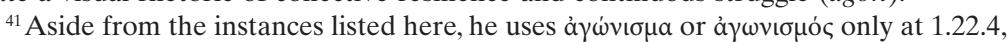
3.82.7, 8.12.2 and 17.2. 


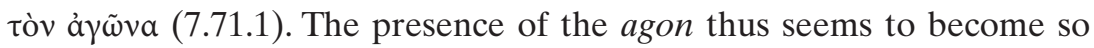
powerful that it expands beyond its usual role, arising between allies and even enveloping the spectators.

A pervasive focus on effort, a key element of the ideology of the agon that is so central to visual and especially funerary depictions of battle, seems almost to displace any discussion of strategy or maneuvers. Thucydides introduces the sea battle as "strong, and the likes of which had not happened before" (7.70.2). The agon shows itself again in the verbs for effort governing many of the combatants' actions, as the Athenians attempt to free themselves from the harbor (i் $\varepsilon \varepsilon 1 \rho \tilde{\omega} v \tau$.

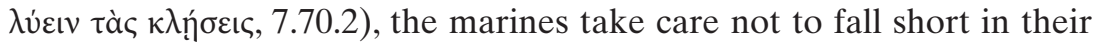

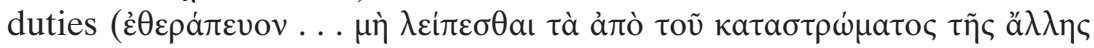
$\tau \dot{\varepsilon} \chi \vee \eta \varsigma, 7.70 .3)$, and all sides try to board each other's ships ( $\dot{\varepsilon} \pi \varepsilon \iota \rho \tilde{\omega} \nu \tau$...

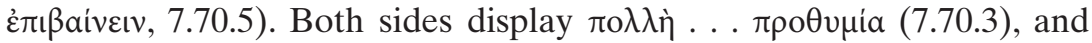
the men are described with the participle $\pi \rho 0 \theta v \mu o v \mu \varepsilon \dot{v o v}$ instead of the more common adverb, ${ }^{42}$ the unusual vocabulary calling attention to their eagerness for the fight (7.70.8). As individual figures in scenes of combat in friezes do, each man individually struggles to prove his excellence, with

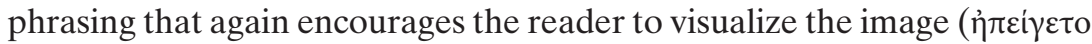
$\pi \rho \tilde{\omega} \tau о \varsigma, \varphi \alpha i v \varepsilon \sigma \theta \alpha \iota, 7.70 .3)$.

Thucydides does not usually share the coyness of his compatriotswhether literary or visual artists-about "low-class" naval war, instead seeming to revel in recounting the strategies and maneuvers seamanship demands. He similarly displays no aversion to phalanx warfare. His interest in and capacity for analyzing phalanx and naval encounters are in fact some of the more impressive features of his work, and in the departure scene from the Piraeus, he appears to go so far as to minimize the presence of the more upper-class hoplites (Steiner 2005, 408-11). But in the Great Harbor narrative, he performs a sleight-of-hand reminiscent of Democleides' tomb, discussed above, in representing a naval battle as essentially hoplitic, a contest of valor and strength rather than cunning and maneuvers. Thucydides focuses much of his attention on the efforts of the marines, who fight in emphatically hoplitic hand-to-hand conflict, albeit from the decks of their ships. In his penultimate speech, Nicias lays the groundwork, presenting the coming conflict as "similar to a land-battle on board ships" (7.62.2), a point he repeats (7.62.4). He claims that the tight quarters of the fight will demand land troops who would not usually

\footnotetext{
${ }^{42}$ Participial forms appear in Thucydides at 5.71.1,6.31.3, and this passage. The adverb and adjective are ubiquitous.
} 
be on board (7.62.2). So closely will the battle resemble land war, that Nicias' goal for the troops is that they avoid allowing themselves to be pushed back (7.63.1) $\dot{\varepsilon} \xi \omega \theta \varepsilon \tilde{\sigma} \sigma \theta \alpha$, recalling the famous $\dot{\omega} \theta$ เ $\sigma$ ó (4.96.2), a technique that in itself means that bodies are crushed as closely together as possible. Instead, the general urges his troops to shove the hoplites from the opposing decks (7.63.1). ${ }^{43} \mathrm{He}$ directs his remarks largely

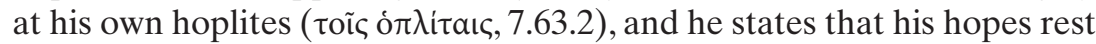
with the land forces on board $(\tau \tilde{\omega} \pi \varepsilon \zeta \tilde{\omega})$. This extensive analysis of the nature of the coming violence leaves little doubt that, while it takes place on water, the Athenians' final chance at salvation nonetheless depends on hoplite soldiers and hoplite tactics. The validity of this assessment is confirmed when Thucydides echoes it, pointing out that there is little possibility of maneuvering the ships (7.70.4). He characterizes the following violence as a series of $\pi \rho \circ \sigma \beta o \lambda a i$ (7.70.4), a word that in the plural usually describes assaults in land warfare ${ }^{44}$ but is used for a naval attack only twice elsewhere in Thucydides' work, and in those cases in the singular. ${ }^{45}$ The soldiers even employ elements of the land itself, "using javelins and arrows

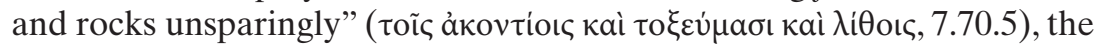
rocks a particularly surprising weapon recalling warfare on shore (e.g.,

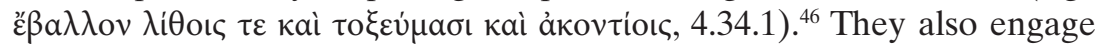

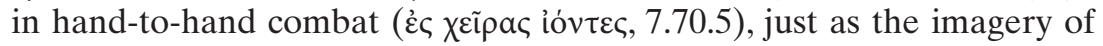
battle often features a series of individual conflicts rather than a phalanx.

In addition to emphasizing the actions of the more heroic, hoplitic troops, Thucydides describes remarkably flawless action on the part of the Athenians for this stage of the Sicilian Expedition. Previous and subsequent conflicts are presented as plagued by mounting Athenian incompetence and disorder, ${ }^{47}$ and disease and exhaustion afflict their

${ }^{43}$ Pritchett $4.65-8$ discusses pushing as a technique in land warfare in ancient historians. He does not mention any occurrences of pushing in naval war.

${ }^{44}$ E.g., Aesch. Th. 28; Hdt. 3.158.1; 4.128.3; Th. 2.4.1; 18.1; 3.1.2; 5.61.4.

${ }^{45}$ The singular is used to describe a naval attack twice in book eight $(8.31 .3,100.4)$.

${ }^{46}$ Pritchett 5.60 lists this battle as the first of only a handful in ancient literature in which stones are used from onboard a ship.

${ }^{47}$ For just a few examples, in an earlier battle the Athenians become disordered (7.37.3) and embark on their ships "in a great uproar" (40.3), "with difficulty and in no

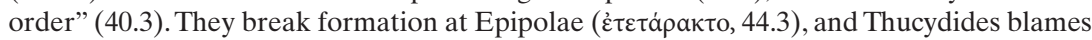
the Athenian side's chaos for his difficulty in ascertaining the events of that night (44.1). Gylippus urges his allies to take advantage of the Athenian á $\tau \alpha \xi i \alpha$ (68.1). Despite Nicias'

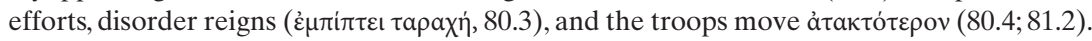
Demosthenes' forces become disordered after they panic at night (81.2) and fall into an uproar when surrounded by Sicilians ( $\dot{\varepsilon} v \pi \mathrm{o} \lambda \lambda \tilde{\omega}$ Өo 
entire army $(7.48 .1 ; 7.50 .3 ; 7.63 .4)$, while the ships, lacking access to a dry dock, have become waterlogged and decay (7.12.3). But in this particular battle, unlike those that surround it, the historian does not mention any Athenian weakness, sickness or lack of discipline, instead producing a picture of two dangerous and impressive foes in an impossibly crowded field at the climactic moment of a life-or-death struggle, an image resembling those the residents of ancient Athens might encounter daily in their city.

The perception of this battle as a visual experience is enhanced by Thucydides' employment of a verbal technique familiar from other literary sources that engage with the visual arts, a strong preference for the imperfect tense..$^{48}$ This use of the tense for ekphrasis is already established in the earliest literature, as Homer favors it to describe action on

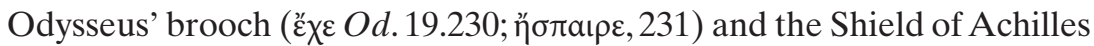

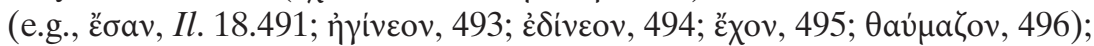
elsewhere, the imperfect in his battle scenes helps create a more vivid visualization of the scene (Clay 2011,63-95). Although the Gigantomachy in Euripides' Ion is unusual, in that it describes the image in the present tense as viewers perceive it in "real time," 49 the tapestry scene in the same

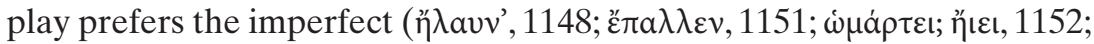

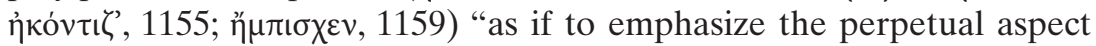
of the activities portrayed on the textiles." ${ }^{50}$ Euripides' representation of

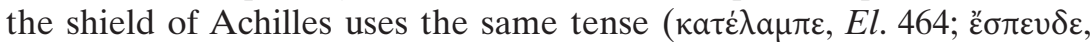

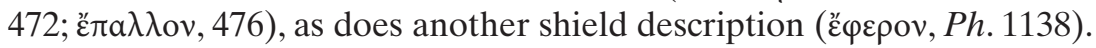
The tragedian's description of Achilles' race against Eumelos' chariot in Iphigenia at Aulis may borrow from ekphrasis (Zeitlin 1995, 183), and

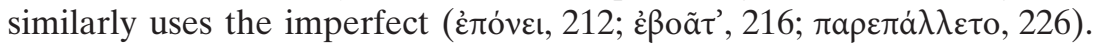
Aeschylus inverts this preference in his description of Iphigeneia gazing pitiably around like a painting ( $A g .240)$, herself doing the viewing in the imperfect, and scholars have noted that the tense fits the simile well. ${ }^{51}$ In all of these scenes, the imperfect hints at a key distinction between physical objects and literary works, namely that physical art stops narrative progress in a way that literature normally does not, as Pindar observes

\footnotetext{
${ }^{48}$ Stansbury-O'Donnell 1995, 322-3, observes this tendency on the Iliad's Shield of Achilles.

${ }^{49}$ For a thorough discussion of this Gigantomachy, see Stieber 2011, 284-302.

${ }^{50}$ Stieber 2011, 311. On the tapestry in Ion, see Stieber 2011, 303-14.

${ }^{51}$ Fraenkel 1950, 138. O'Sullivan 2008, 181, contrasts it with surrounding aorists: "The imperfect form eballe ( $A g .240)$ is significant here too, as it invites us to linger over Iphigeneia as a pitiable image."
} 
in his critique of the stillness of statuary (N. 5.1). ${ }^{52} \mathrm{~A}$ defining feature of scenes of ekphrasis is thus a dramatic slowing of time as the reader lingers over an image that is fixed like those in the visual arts are-or, as in the case of the Shield of Achilles, one that appears mysteriously to move despite its solid material nature.

Like these authors of ekphrastic scenes, Thucydides relies heavily on the imperfect to compose his spectacle, creating a tableau that seems to be a static representation of continuous action. Other conflicts in his work tend to employ a variety of tenses,$^{53}$ often with a preference for the aorist. But nearly every main verb in this passage is in the imperfect, some of them among only a few appearances of the individual verb in this tense in Thucydides' work..$^{54}$ For the majority of the battle (7.70-71.5), every main verb is imperfect, apart from two aorists in an aside by the

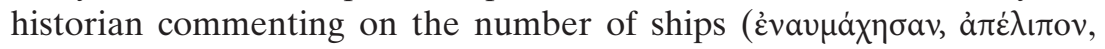
7.70.4). ${ }^{55}$ Even a word that seems by nature to describe a single moment,

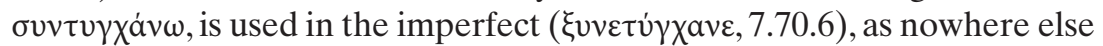
in Classical literature. These imperfects seem to hold the men mid-motion, stopping the progress of the battle as all the combatants persist in the action they are performing, like a still image of the mêlée.

Thucydides' explicit statements also seem to fix the battle in time, much as a painting or an architectural relief might appear to preserve an agon in its decisive moment. He emphasizes the prolonged period in which

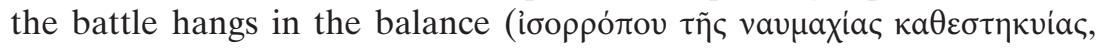

${ }^{52} \mathrm{G}$. E. Lessing observes that visual depictions of events exist in space, literary depictions in time (Laokoon 16). Part of the appeal of ekphrasis is that it plays with stopping this progress of time. For time in ekphrasis, see Stansbury-O'Donnell 1995, Clay 2011,33-6.

${ }^{53} \mathrm{Cf}$. the more usual mix of verbs in the conflict on Pylos, the other extraordinarily

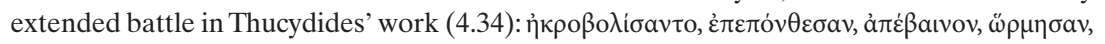

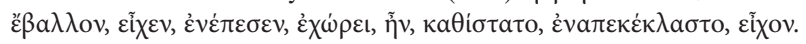

${ }^{54}$ Imperfect forms of $\eta \jmath \omega \dot{\omega} \omega v(7.70 .8)$ appear twice elsewhere $(3.52 .4 ; 8.92 .10)$;

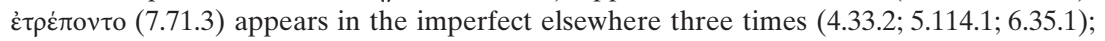

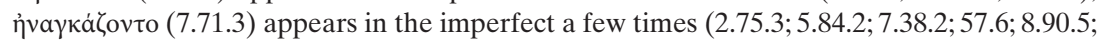

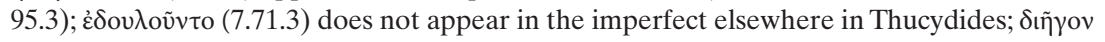

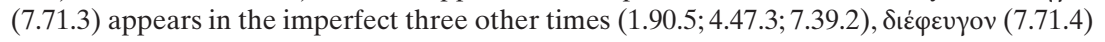

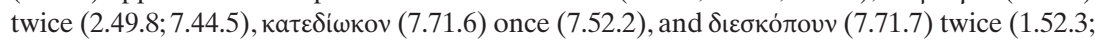
6.59.2). On significant use of the imperfect in Herodotus, see Rösler 2002, 91-3.

${ }^{55}$ Bakker 1997, 12-13, notes that 7.70 .2 would normally be expected to be presented in the aorist, arguing for a more nuanced distinction between uses of the imperfect and the aorist than is often found. Elsewhere, Bakker 2007, 118, also observes the striking dependence on imperfects in this battle, arguing that use of them puts us even more firmly in the role of the spectators. For the argument, see also Bakker 1997, 41-2. 
7.71.1) and describes the viewers' responses to the protracted indecision

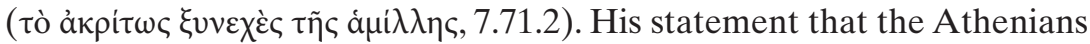

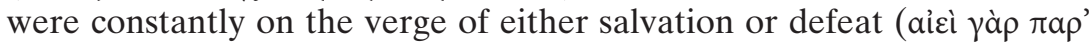

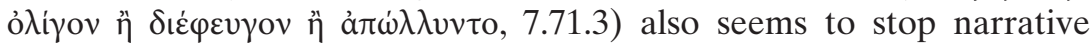
progress, as well as recalling the situation of men depicted on tombs. Just before the Athenians collapse, Thucydides once again observes that the

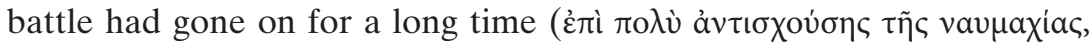
7.71.5), and his description of the emotions of the watching army "as long as they were fighting equally" ( $\ddot{\varepsilon} \omega \varsigma \grave{\alpha} \gamma \chi \dot{\omega} \mu \alpha \lambda \alpha \dot{\varepsilon} v a v \mu \alpha \dot{x} \chi o v v, 7.71 .4)$ implies that the battle remained at its acme for a considerable period of time. Verbs return to a more normal distribution of imperfects and aorists after the Athenian defeat, at which point the image dissolves and the action

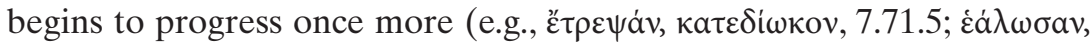
$\dot{\varepsilon} \xi \dot{\varepsilon} \pi \varepsilon \sigma o v, \pi \alpha \rho \varepsilon \beta o \eta \dot{\theta o v v, ~ 71.6) . ~}$

As noted above, graves, architectural sculptures, and other visual representations of battle usually have similar appearances, and on its own, the "picture" created by Thucydides might belong to any or all of these categories. Other linguistic choices, however, associate the Great Harbor episode specifically with tombs rather than with battle imagery more generally. Nicias' jarringly epitaphic speech immediately preceding the event, as well as the mass casualties the reader knows impend, create a funereal setting even before the spectacle takes shape. Proper rituals for the dead are also at the forefront of the reader's mind because of their conspicuous absence, with Thucydides pointing out afterward that the Athenian dead are left where they fall rather than being collected (7.72.1), and a contemporary audience would be well aware of this grim fact before learning of it in Thucydides' text. The historian also overlays the scene with the sounds and actions appropriate to a funeral. Hornblower observes that a word used for the exaltation of those celebrating

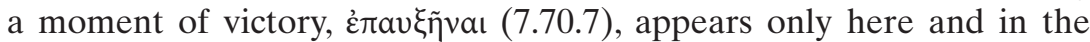
Funeral Oration; that the thea of 7.71.3 may suggest Homer's description of Patroclus' funeral games in Iliad 23; and that the "wailing and groan-

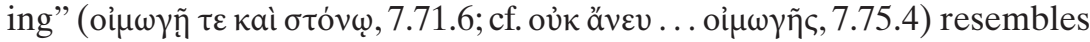
Il. 24.696, where Hector's body is returned to Troy (Hornblower 2008, $697,701 ; 2004,345)$. The latter term, which appears only in this section of Thucydides, is particularly associated with grieving (Arnould 1990,155).

Other features build on the funereal atmosphere that encourages a reading of the Great Harbor spectacle in the same light. Variations

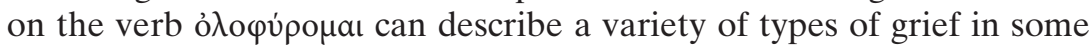
authors (e.g., Hom. Il. 5.871; Od. 10.409, 22.232; Pl. R. 329a), but in other authors and contexts the word is associated specifically with mourning for 
the dead (e.g., Lys. 2.71, 77, 81). ${ }^{56}$ Thucydides tends to use it in this more specific sense, and typically not in battle scenes. Thus it appears in the

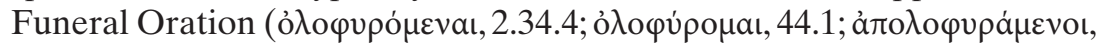

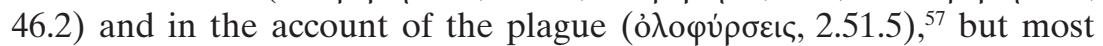
strikingly in the Great Harbor battle, where it is found repeatedly. ${ }^{58}$ The

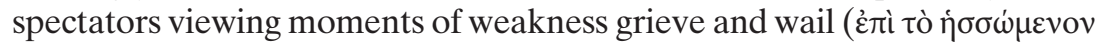

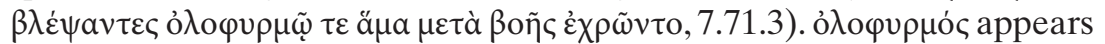
on the scene, the unusual substantive encouraging the reader to take notice (7.71.4). After the battle, it is used again when the dying wail as

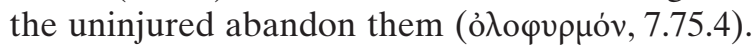

The eventual departure of the survivors also mimics that of mourners participating in a funeral. The men remain on the beach, in view of the bodies of their comrades, until the third day, the typical length of a prosthesis. ${ }^{59}$ The third day ( funeral procession, sees these men, too, march away the bodies of their friends, grieving like mourners might. After a typical death, this would be the day for the burial, so it is fitting that it is at this point that the

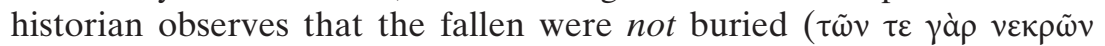
$\dot{\alpha} \tau \dot{\alpha} \varphi \omega v$ óv $\tau \omega v, 7.75 .3)$. The departure from the beach nonetheless recalls

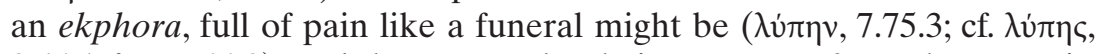
$2.44 .1 ; \lambda \dot{v} \pi \eta, 44.2)$, and the men make their way away from the scene in tears (7.75.4). Thucydides himself seems to participate in this grief when

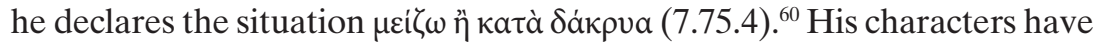
thus mimicked many important stages of a funeral, listening to Nicias' epitaphios logos, contemplating the impressive image of their comrade's last valorous battle, and making a grief-stricken departure, and Thucydides will soon provide the doomed Nicias with an epitaph, as well.

${ }^{56}$ On words deriving from the ỏ $\curlywedge$ o $v \rho$ - stem as Homeric, see Allison 1997, 503.

${ }^{57}$ It also appears in his statement on the magnitude of the tragedy at Mycalessus (7.30.3) and the feeling one might have toward dead ancestors (3.67.2).

${ }^{58}$ While the presence of sound or speech might seem to undermine an argument that the episode should be visualized, Greek visual art not infrequently involves verbal expres-

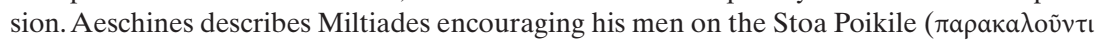

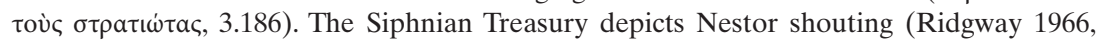
197), and speech is a prominent feature of the Shield of Achilles. See also Harrison 1972, 356. Svenbro 1993, 176-7, discusses instances of "seeing noise" that occur in lines "spoken" through grammata by figures in visual arts. Marinis 2012 discusses similar cases of mixed imagery of sound and sight.

${ }^{59}$ On these rituals, see esp. Pritchett 4.100-6. Alexiou 2002, 6-7, also discusses them, citing Th. 2.34; Ar. Lys. 612; Pl. Lg. 959a.

${ }^{60}$ Hornblower 2008,710 , notes that these are the only two appearances of tears in Thucydides. 


\section{THUCYDIDES' HISTORIOGRAPHY AND MEMORIALIZATION}

The apparently pervasive funerary atmosphere in the conclusion of the Sicilian Expedition, one of the most prominent portions of Thucydides' work, suggests that historiography can preserve the memory of the dead much as a tomb does. Taken together, these features contribute a sense of grief and loss both to the Sicilian Expedition narrative and also to Thucydides' text as a whole. This aspect of his work seems to be in keeping with his thoughts on tombs throughout. Early on, he suggested the inadequacy of even proper physical burials. ${ }^{61}$ Although Pericles in his

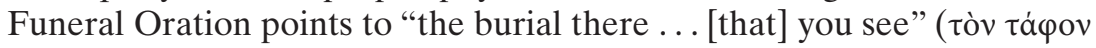

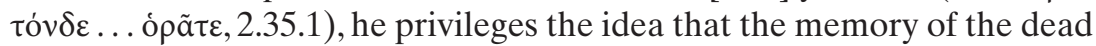
is really preserved in "the most conspicuous tomb, not so much the one in which they lie but rather in which their praise is stored up to be eternally remembered whenever there is a fitting occasion in word and deed. For the whole earth is a tomb for glorious men, and not only the writing on stones in their native land indicates it, but even far away an unwritten memorial lives on, more in the mind of everyone than in an object" $(2.43 .2-3) .{ }^{62}$ This creative and expansive re-definition of tombs for the war dead seems to be realized at the end of the Sicilian Expedition. Here, Thucydides appears to use the language and imagery of funerals and gravestones as a filter through which to present historical events, thus creating a tomb for the Athenians in the minds of his readers, one that can indeed "live in the hearts of men" rather than existing on the physical plane.

Although this reading of the end of the Sicilian Expedition has him overlay his historical narrative with reminiscences of a ritual that was conspicuously absent in real life, it creates little serious conflict between literary artistry and accurate historiography. The shaping of these events is largely a matter of emphasis rather than fact, giving us little reason to doubt the general accuracy of the story. His description of the Great Harbor battle may leave some military historians dissatisfied with the lack of strategic detail, and he seems abruptly to forget the decrepit state of the Athenians' ships and bodies that he has so emphasized elsewhere. The only demonstrable

${ }^{61}$ Literature sometimes goes as far as to challenge the ability of physical arts to memorialize, given their inevitable deterioration. See, e.g., Steiner 1999 on Pindar (P. 6.7-14; N. 5.1-5), Herodotus (1.1) and Simonides (fr. 531). For another study of this issue see also Porter 2010, 510-23. Thucydides is not as explicit as others are, but the end of his Sicilian Expedition seems to hint at a similar challenge.

${ }^{62}$ On Thucydides' equation of fame and epitaph, especially in Pericles' speech, see Porter 2010, 475. 
conflict with historical accuracy, however, is deeming this battle the "greatest number of ships in the narrowest space" (7.70.4), which is to say that literature and history co-exist relatively—if not perfectly—comfortably in this episode.

\section{CONCLUSIONS}

This article has argued that the Great Harbor scene towards the end of Thucydides' Sicilian Expedition serves two complementary purposes. First, it corrects the Athenians' initial delusion about the gravity of their undertaking by presenting the Athenian army as a spectacle for the second time, the later image serving as a far more accurate reflection of the true, deadly, nature of the Sicilian Expedition than the illusionary Piraeus scene had been. Secondly, it serves as a substitute tomb for the fallen Athenians when they pay the price for this hubristic miscalculation. At its opening, the Athenians treat the Sicilian Expedition as a lighthearted contest with affinities to athletic competition, an endeavor that offers visual pleasure for the spectators in the harbor and will also satisfy the participants' desire for ö $\psi \varepsilon \omega \varsigma$ кaì $\theta \varepsilon \omega p i a \varsigma$ in Sicily (6.24.3). The next spectacle, however, offers a terrible clarification of the nature of what the Sicilian Expedition represents. The funerary overtones of the corresponding spectacle at the end of the Expedition make clear that the Sicilian Expedition is not a playful or athletic competition but a lethal military one, suggesting that the Athenians have fatally misinterpreted their own situation and strength. Even while offering this painful correction, Thucydides' shaping of this final episode suggests that he conceives of his work as serving a purpose at least analogous to a tomb for the fallen Athenians, honoring them much as scholars have argued Nicias' last speech and Thucydides' magnanimous epitaph for the general do. In the conclusion of the Sicilian Expedition, he thus offers a tribute that real life denied the Athenian forces, uncoupling the process of memorialization from the limits of the physical world to create a monument to their valor and resolve in the face of death that, like his work as a whole, continues to exist as a ktema es aiei. ${ }^{63}$

\section{BILKENT UNIVERSITESI}

e-mail: rachelbruzzone@gmail.com

${ }^{63} \mathrm{I}$ am grateful to have had the advice and support of J. E. Lendon, Elizabeth A. Meyer, Benjamin Millis, Hunter R. Rawlings III, Tim Rood, and A. J. Woodman in writing this article. The Society for Classical Studies 2017 "Political and Military Conflict in the 


\section{BIBLIOGRAPHY}

Alexiou, Margaret. 2002. The Ritual Lament in Greek Tradition. Rev. by Dimitrios Yatromanolakis and Panagiotis Roilos. Lanham, Md.: Rowman and Littlefield.

Allison, J. W. 1997. "Homeric Allusions at the Close of Thucydides' Sicilian Narrative." AJP 118: 499-516.

Arnould, Dominique. 1990. Le rire et les larmes dans la littérature grecque. Paris: Belles Lettres.

Arrington, N. T. 2011. "Inscribing Defeat: The Commemorative Dynamics of the Athenian Casualty Lists." CA 30: 179-212.

- 2015. Ashes, Images, and Memories: The Presence of the War Dead in Fifth-Century Athens. Oxford: Oxford University Press.

Bakker, E. J. 1997. "Verbal Aspect and Mimetic Description in Thucydides." In Grammar as Interpretation: Greek Literature in its Linguistic Contexts, ed. E. J. Bakker, 7-54. Leiden: Brill.

- 2007. "Time, Tense, and Thucydides." CW 100: 113-22.

Barlow, S. A. 1971. The Imagery of Euripides. London: Methuen.

Bassi, Karen. 2007. "Spatial Contingencies in Thucydides' History." CA 26:171-218.

- 2016. Traces of the Past: Classics between History and Archaeology. Ann Arbor: University of Michigan Press.

Boardman, John. 1985. Greek Sculpture. London: Thames and Hudson.

Carmona Centeno, David. 2012. "La batalla del Puerto de Siracusa: Tucidides o el imitador de Homero." SemRom 3: 95-115.

Chaniotis, Angelos. 2013. "Empathy, Emotional Display, Theatricality, and Illusion in Hellenistic Historiography." In Unveiling Emotions II, ed. Angelos Chaniotis and Pierre Ducrey, 53-84. Stuttgart: Steiner.

Clairmont, C. W. 1972. "Gravestone with Warriors in Boston." GRBS 13: 49-58. - 1983. Patrios Nomos: Public Burial in Athens during the Fifth and Fourth Centuries B.C. Vol. 1. Oxford: British Archaeological Reports.

Clay, J. S. 2011. Homer's Trojan Theater. Cambridge: Cambridge University Press. Connelly, J. B. 2014. The Parthenon Enigma. New York: Knopf.

de Romilly, Jacqueline. 1956. Histoire et Raison chez Thucydide. Paris: Belles Lettres.

Elsner, Jaś. 2007. "Viewing Ariadne: From Ekphrasis to Wall Painting in the Roman World." CP 102: 20-44.

Fraenkel, Eduard ed. 1950. Aeschylus' Agamemnon. Oxford: Clarendon.

Greek World" panel and AJP's anonymous referees also offered valuable feedback and encouragement. Bernd Steinbock read multiple drafts and shared them with his students. Mark Stansbury-O'Donnell was especially helpful both in reading the article and offering advice on the visual material. 
Goette, H. R. 2009. "Images in the Athenian 'Demosion Sema'." In Art in Athens During the Peloponnesian War, ed. Olga Palagia, 188-206. Cambridge: Cambridge University Press.

Golder, Herbert. 1996. "Making a Scene: Gesture, Tableau, and the Tragic Chorus." Arion 4: 1-19.

Grethlein, Jonas. 2008. "Eine herodoteische Deutung der sizilischen Expedition (Thuc. 7.87.5f)?" Hermes 136: 129-42.

Grossman, J. B. 2001. Greek Funerary Sculpture. Los Angeles: J. Paul Getty Museum.

. 2013. The Athenian Agora: Funerary Sculpture. Princeton: American School of Classical Studies at Athens.

Harrison, E. B. 1972. "The South Frieze of the Nike Temple and the Marathon Painting in the Painted Stoa." AJA 76: 353-78.

Hornblower, Simon. 2004. Thucydides and Pindar. Oxford: Oxford University Press.

- 2008. A Commentary on Thucydides, vol. 3. Oxford: Oxford University Press.

Hunt, Peter. 1998. Slaves, Warfare, and Ideology in the Greek Historians. Cambridge: Cambridge University Press.

Hurwit, J. M. 1999. The Athenian Acropolis: History, Mythology, and Archaeology from the Neolithic Era to the Present. Cambridge: Cambridge University Press.

. 2007. "The Problem with Dexileos: Heroic and Other Nudities in Greek Art." AJA 111: 35-60.

Jordan, Borimir. 2000. "The Sicilian Expedition Was a Potemkin Fleet." $C Q$ 50: 63-79.

Jouan, François. 1966. Euripide et les légendes des chants cypriens. Paris: Belles Lettres.

Kallet, Lisa. 2001. Money and the Corrosion of Power in Thucydides. Berkeley: University of California Press.

Lattimore, R. A. 1942. Themes in Greek and Latin Epitaphs. Urbana, Ill.: University of Illinois Press.

Lendon, J. E. 2005. Soldiers and Ghosts. New Haven: Yale University Press.

- 2017. "Battle Description in the Ancient Historians Part II: Speeches, Results, and Sea Battles." G\&R 64: 145-67.

LeVen, P. A. 2013. “'You Make Less Sense than a (New) Dithyramb:' Sociology of a Riddling Style." In The Muse at Play: Riddles and Wordplay in Greek and Latin Poetry, ed. Jan Kwapisz, et al., 44-64. Berlin: De Gruyter.

Loraux, Nicole. 1981. The Invention of Athens: The Funeral Oration in the Classical City. Trans. Alan Sheridan, 2006. Cambridge, Mass.: MIT Press.

Mackie, C. J. 1996. "Homer and Thucydides: Corcyra and Sicily." CQ 46: 103-13.

Marinis, Agis. 2012. "Seeing Sounds: Synaesthesia in the Parodos of Seven Against Thebes." Logeion 2: 26-59.

Meyer, E. A. 1993. "Epitaphs and Citizenship in Classical Athens.” JHS 113:99-121. 
Miller, M. C. 2010. "I am Eurymedon:Tensions and Ambiguities in Athenian War Imagery." In War, Democracy and Culture in Classical Athens, ed. D. M. Pritchard, 304-38. Cambridge: Cambridge University Press.

Morris, Ian. 1992. Death-Ritual and Social Structure in Classical Antiquity. Cambridge: Cambridge University Press.

Muth, Susanne. 2008. Gewalt im Bild: Das Phänomen der medialen Gewalt im Athens des 6. und 5. Jahrhunderts v. Chr. Berlin: De Gruyter.

Ober, Josiah. 1998. Political Dissent in Democratic Athens: Intellectual Critics of Popular Rule. Princeton: Princeton University Press.

Osborne, Robin. 1994. "Framing the Centaur: Reading Fifth-Century Architectural Sculpture." In Art and Text in Ancient Greek Culture, ed. Simon Goldhill, and Robin Osborne, 52-84. Cambridge: Cambridge University Press.

-1998. Archaic and Classical Greek Art. Oxford: Oxford University Press. . 2010. "Democratic Ideology, the Events of War and the Iconography of Attic Funerary Sculpture." In War, Democracy and Culture in Classical Athens, ed. D. M. Pritchard, 245-65. Cambridge: Cambridge University Press.

O’Sullivan, Patrick. 2008. "Aeschylus, Euripides, and Tragic Painting: Two Scenes from Agamemnon and Hecuba." AJP 129: 173-98.

Parlama, Liana, and Nicholas Stampolidis. 2000. Athens: The City Beneath the City. Antiquities from the Metropolitan Railway Excavations. Athens: Kapon.

Porter, J. I. 2010. The Origins of Aesthetic Thought in Ancient Greece. Cambridge: Cambridge University Press.

Pritchett, W. K. 1975-91. The Greek State at War. 5 vols. Berkeley: University of California Press.

Rawlings, H. R. R. III. 1981. The Structure of Thucydides' History. Princeton: Princeton University Press.

Rehm, Rush. 1994. Marriage to Death: The Conflation of Wedding and Funeral Rituals in Greek Tragedy. Princeton: Princeton University Press.

Richter, G. M.A. 1954. Catalogue of Greek Sculptures. Cambridge, Mass.: Harvard University Press.

Ridgway, B. S. 1966. "Notes on the Development of the Greek Frieze.” Hesperia 35: 188-204.

Rood, Tim. 1998. Thucydides: Narrative and Explanation. Oxford: Oxford University Press.

Rösler, Wolfgang. 2002. "The Histories and Writing." In Brill's Companion to Herodotus, ed. E. J. Bakker, et al., 79-94. Leiden: Brill.

Schultz, Peter. 2009. "The North Frieze of the Temple of Athena Nike." In Art in Athens During the Peloponnesian War, ed. Olga Palagia, 128-67. Cambridge: Cambridge University Press.

Shapiro, H. A. 1991. "The Iconography of Mourning in Athenian Art." AJA 95: 629-56.

Snodgrass, A. M. 1967. Arms and Armor of the Greeks. Ithaca: Cornell University Press. 
Sousa e Silva, M. de F. 1985-6. "Elementos visuais e pictóricos na tragédia de Eurípides." Humanitas 37-8: 9-86.

Stansbury-O'Donnell, M. D. 1995. "Reading Pictorial Narrative: The Law Court Scene of the Shield of Achilles." In The Ages of Homer, ed. J. B. Carter and S. P. Morris, 315-34. Austin: University of Texas Press.

. 1999. Pictorial Narrative in Ancient Greek Art. Cambridge: Cambridge University Press.

Steinbock, Bernd. 2017. "The Contested Memory of Nicias after the Sicilian Expedition." In Conflict in Communities. Forward-looking Memories in Classical Athens, ed. Elena Franchi and Giorgia Proietti, 109-70. Trient: Università degli Studi di Trento.

Steiner, D. T. 1998. "Moving Images: Fifth-Century Victory Monuments and the Athlete's Allure." CA 17: 123-50.

. 1999. "To Praise, Not to Bury: Simonides fr. 531P." CQ 49: 383-95.

2001. Images in Mind: Statues in Archaic and Classical Greek Literature and Thought. Princeton: Princeton University Press.

- 2005. "For Want of a Horse: Thucydides 6.30-2 and Reversals in the Athenian Civic Ideal." CQ 55: 407-22.

Stewart, Andrew. 1990. Greek Sculpture: An Exploration. Vol. 1. New Haven: Yale University Press.

Stieber, Mary. 1998. "Statuary in Euripides' Alcestis." Arion 5: 69-97.

- 2011. Euripides and the Language of Craft. Leiden: Brill.

Strauss, B. S. 2000. "Perspectives on the Death of Fifth-Century Athenian Seamen." In War and Violence in Ancient Greece, ed. Hans van Wees, 261-83. London: Classical Press of Wales.

Stupperich, Reinhard. 1994. "The Iconography of Athenian State Burials in the Classical Period." In The Archaeology of Athens and Attica under the Democracy, ed. W. D. E. Coulson et al., 93-103. Oxford: Oxbow.

Svenbro, Jesper. 1993. Phrasikleia: An Anthropology of Reading in Ancient Greece. Trans. Janet Lloyd. Ithaca: Cornell University Press.

Swift, Laura. 2015. "Lyric Visions of Epic Combat:The Spectacle of War in Archaic Personal Song." In War as Spectacle: Ancient and Modern Perspectives on the Display of Armed Conflict, ed. Anastasia Bakogianni and V. M. Hope, 93-109. London: Bloomsbury.

Vernant, J.-P. 1982. "La belle mort et le cadavre outragé." In La mort, les morts dans les sociétés anciennes, ed. Gherardo Gnoli and J.-P. Vernant, 45-76. Cambridge: Cambridge University Press.

Walker, A. D. 1993. "Enargeia and the Spectator in Greek Historiography.” TAPA 123: 353-77.

Walter-Karydi, Elena. 2015. Die Athener und ihre Gräber (1000-300 v. Chr.). Berlin: De Gruyter.

Webb, Ruth. 2009. Ekphrasis, Imagination and Persuasion in Ancient Rhetorical Theory and Practice. Burlington, Vt.: Ashgate. 
Wills, Jeffrey. 1996. Repetition in Latin Poetry. Oxford: Clarendon.

Zeitlin, F. I. 1994. "Ecphrasis and Spectacle in Euripides." In Art and Text in Ancient Greek Culture, ed. Simon Goldhill and Robin Osborne, 138-96. Cambridge: Cambridge University Press.

. 1995. "Art, Memory, and Kleos." In History, Tragedy, Theory: Dialogues on Athenian Drama, ed. Barbara Goff, 174-201. Austin: University of Texas Press.

Ziolkowski, J. E. 1985. Thucydides and the Tradition of Funeral Speeches at Athens. New York: Arno. 